\title{
Role of RANKL in the regulation of NFATc1 and c-Src mRNA expression in osteoclast-like cells
}

\author{
JIFAN FU*, YOU DI TAO* , JIAN CHEN, YONGSHENG ZHANG and JIANQUAN HE \\ Department of Rehabilitation, Zhongshan Hospital of Xiamen University, \\ Xiamen University, Xiamen, Fujian 361004, P.R. China
}

Received May 22, 2015; Accepted March 22, 2016

DOI: $10.3892 / \mathrm{mmr} .2016 .5176$

\begin{abstract}
This study was designed to determine the effects of receptor activator of nuclear factor $\kappa B$ ligand (RANKL) on the mRNA expression of nuclear factor of activated T-cells, cytoplasmic, calcineurin-dependent 1 (NFATc1) and c-Src in rat osteoclast-like cells. The marrow cells were exposed to macrophage colony-stimulating factor (M-CSF; $25 \mathrm{ng} / \mathrm{ml})$ and different concentrations of RANKL (0, 50, 75 and $100 \mathrm{ng} / \mathrm{ml}$ ) for 9 days. The mRNA expression of NFATc1 and c-Src was determined by polymerase chain reaction. Compared with the M-CSF $(25 \mathrm{ng} / \mathrm{ml})+\mathrm{RANKL}$ (0 ng/ml) group, the levels of NFATc1 and c-Src mRNA expression were significantly increased in the M-CSF $(25 \mathrm{ng} / \mathrm{ml})+\mathrm{RANKL}(75$ and $100 \mathrm{ng} / \mathrm{ml})$ groups $(\mathrm{P}<0.01$, $\mathrm{P}<0.01, \mathrm{P}<0.01$ and $\mathrm{P}<0.01$, respectively). Compared with the M-CSF (25 ng/ml)+RANKL (50 ng/ml) group, the levels of NFATc1 and c-Src mRNA expression was significantly increased in the M-CSF $(25 \mathrm{ng} / \mathrm{ml})+\mathrm{RANKL}$ (75 and $100 \mathrm{ng} / \mathrm{ml})$ groups $(\mathrm{P}<0.05, \mathrm{P}<0.01, \mathrm{P}<0.01$ and $\mathrm{P}<0.01$, respectively). Compared with $\mathrm{M}-\mathrm{CSF}(25 \mathrm{ng} / \mathrm{ml})+\mathrm{RANKL}$ (75 $\mathrm{ng} / \mathrm{ml}$ ) group, the levels of NFATc1 and c-Src mRNA expression was significantly increased in the M-CSF (25 ng/ml)+RANKL (100 ng/ml) group, $(\mathrm{P}<0.01$ and $\mathrm{P}<0.01$, respectively). These data suggest that $\mathrm{RANKL}$ could regulate the expression of NFATc1 and c-Src mRNA in the marrow culture system.
\end{abstract}

Correspondence to: Professor Jian Chen, Department of Rehabilitation, Zhongshan Hospital of Xiamen University, Xiamen University, 201-209 Hubin South Road, Xiamen, Fujian 361004, P.R. China

E-mail: chenjian5@medmail.com.cn

${ }^{*}$ Contributed equally

Key words: osteoclast-like cell, receptor activator of nuclear factor $\kappa \mathrm{B}$ ligand, receptor activator of nuclear factor $\mathrm{\kappa B}, \mathrm{c}-\mathrm{Src}$, nuclear factor of activated T-cells, cytoplasmic, calcineurin-dependent 1

\section{Introduction}

The balance between the formation of osteoblasts and osteoclast resorption is key in bone remodeling. An imbalance between the osteoclasts and osteoblasts leads to various bone-related disorders, such as osteoporosis, osteomalacia and osteopetrosis $(1,2)$. Osteoclasts are derived from hematopoietic cells of the monocyte/macrophage lineage that are responsible for bone resorption. Receptor activator of nuclear factor- $\kappa \mathrm{B}$ (RANK) and its cognate ligand (RANKL) are a tumor necrosis factor (TNF) superfamily receptor-ligand pair that are essential in bone remodeling, immune function and mammary gland development, in conjunction with various cytokines and hormones (3-6). RANKL is a type II homotrimeric transmembrane protein and it is the central regulator of the differentiation, activation, and survival of osteoclasts which are the primary cells for physiological and pathological bone resorption (7). RANKL-induced activation of RANK on the surface of osteoclast progenitor cells leads to the stimulation of TNF receptor-associated factors (TRAFs) and the subsequent activation of several downstream signaling molecules, including nuclear factor- $\kappa \mathrm{B}$ $(\mathrm{NF}-\kappa \mathrm{B})$, mitogen-activated protein kinases (MAPKs), activating protein 1 (AP-1), nuclear factor of activated $\mathrm{T}$ cells cytoplasmic, calcineurin-dependent 1 (NFATc1), and phosphatidylinositol 3-kinase, resulting in the differentiation of osteoclast progenitor cells into cells that finally fuse to form multinucleated bone-resorbing osteoclasts $(8,9)$. These signaling pathways ultimately lead to the induction and activation of the transcription factors involved in the expression of genes that characterize osteoclasts.

Recent studies have revealed that NFATc1 is a critical transcription factor in osteoclastogenesis. NFAT is a calcineurin and calcium-regulated transcription factor. The release of $\mathrm{Ca}^{2+}$ activates the calmodulin-regulated phosphatase calcineurin, which binds to the N-terminal domain of NFATc1 and dephosphorylates it $(10,11)$. NFATc1-deficient embryonic stem cells can not differentiate into osteoclasts. The overexpression of constitutively active NFATc1 in bone marrow monocytes/macrophages causes precursor cells to undergo efficient differentiation even in the absence of RANKL. Suggesting that NFATc1 is important for osteoclastogenesis (10-13). NFATc1 undergoes nuclear translocation and regulates the expression of a number of osteoclast specific 
genes, such as cathepsin K, TRAP, calcitonin receptor as well as NFATc1 itself (12). The expression of NFATc1 appeared to be induced by RANKL stimulation, and the suppression or knockdown of NFATc1 inhibits RANKL-induced osteoclastogenesis in vitro (13). c-Src is critical to the function of osteoclasts, but not for osteoclast formation (14). Osteoclasts deficient in c-Src do not develop normal podosomes, cannot give rise to mature superstructures and fail to move properly (15). In addition, osteoclasts deficient in c-Src exhibit reduced motility and abnormal organization of the ruffle border and lack the cytoskeletal elements which are required for bone resorption.

Our previous study showed that RANK/RANKL/osteoprotegerin (OPG) may modulate the process of osteoclast activation and subsequent bone resorption (16). However, the different concentrations of RANKL impact NFATc1 and c-Src expression in osteoclast-like cells remains unknown. In this study, RANKL regulation of the gene expression of NFATc1 and c-Src in osteoclast-like cell cultures derived from the bone marrow of rats and the underlying molecular mechanism were investigated.

\section{Materials and methods}

Animals. Five-week-old female Sprague Dawley rats, weighing 120-130 g, were purchased from the Medical College of Xiamen University Laboratory Animal Center (Xiamen, China; certificate no. 2007-0005). The rats were maintained at $22 \pm 2^{\circ} \mathrm{C}$ and $60 \%$ humidity with good ventilation, an alternate $12 \mathrm{~h}$ natural light-dark cycle, and unlimited access to standard rat food and tap water. This study was approved by the medical ethics committee of the Zhongshan Hospital of Xiamen University and conformed to National Institutes of Health guidelines regarding animal experimentation.

Reagents. The 387A-1 kit used for cytological staining, obtained from Sigma-Aldrich (St. Louis, MO, USA). $\alpha$-minimum essential medium ( $\alpha$-MEM) was obtained from Hyclone (Logan, UT, USA). Fetal bovine serum (FBS) was obtained from (Biological Industries, Beit-Haemek, Israel). Soluble recombinant rat RANKL and M-CSF were obtained from PeproTech (Rocky Hill, NJ, USA). TRIzol was obtained from Invitrogen, Thermo Fisher Scientific Inc. (Waltham, MA, USA). DNA markers were obtained from TIANGEN Biotech (Beijing) Co., Ltd. (Beijing, China). The RevertAid First Strand cDNA Synthesis kit was obtained from Thermo Fisher Scientific Inc. Primer sequences were obtained from Invitrogen, Thermo Fisher Scientific Inc. All other chemicals were obtained from Sigma-Aldrich.

Osteoclast-like cell formation in rat marrow culture. Rat bone marrow cells were harvested as previously described (16-18) with minor modifications. Briefly, rat bone marrow cells were harvested 12 weeks after ovariectomy by a previous method (17) with minor modifications. For superficial antisepsis, the sacrificed rats by cervical dislocation and decapitation without anesthesia and were soaked twice for 5 min in $1 \%$ iodophors liquid (Shanghai Likang Disinfection Technology Co., Ltd., Shanghai, China). Deiodination was completed with $75 \%$ alcohol. After rapid removal of soft tissues under aseptic conditions, the femors and tibias were cleaned twice with phosphate-buffered saline (PBS, pH 7.4). They were then rinsed twice with $\alpha$-minimum essential medium (Invitrogen, Thermo Fisher Scientific, Inc.). Bone marrow cells were obtained from the femors and tibias of the Sprague Dawley rats by flushing the marrow space with $\alpha$-MEM containing $15 \%$ FBS. The cells were then seeded into 6-well chamber slides (Nalge Nunc International, Naperville, IL, USA) at $2 \mathrm{ml}$ cell suspension/well in $\alpha$-MEM containing FBS. The bone slices were used for observe bone resorptive lacunae. The glass slides were used for TRAP staining. After 9 days of culture with osteoclast-like cells, the bone slices and glass slides were removed for observation. After $5 \mathrm{~h}$, non-adherent cells were removed with $\alpha$-MEM. Half the medium was replaced every day with fresh medium. Bone marrow cells were cultured in $\alpha$-MEM with $10 \%$ FBS containing $25 \mathrm{ng} / \mathrm{ml} \mathrm{M}$-CSF. After $24 \mathrm{~h}$, non-adherent cells were collected and plated on a 6-well microplate at a density of $1 \times 10^{6}$ cells $/ \mathrm{cm}^{2}$ and cultured for up to 9 days in $\alpha$-MEM containing $10 \%$ FBS with $25 \mathrm{ng} / \mathrm{ml} \mathrm{M}-\mathrm{CSF}$ and $0,50,75$ or $100 \mathrm{ng} / \mathrm{ml}$ RANKL.

Tartrate-resistant acid phosphatase (TRAP) assays. Osteoclast formation was evaluated using TRAP staining with the formation of multiple nuclei. After $72 \mathrm{~h}$ of culture, growing cells were removed and dried at room temperature. The cells were fixed in 2.5\% (v/v) glutaraldehyde (Shanghai Ponsurebio Co., Ltd., Shanghai, China) at $4^{\circ} \mathrm{C}$ for $10 \mathrm{~min}$. TRAP staining fluid (Sigma-Aldrich) was added, and the plates were incubated at $37^{\circ} \mathrm{C}$ for an additional $50 \mathrm{~min}$. After the removal of the TRAP solution using a transferpettor, the plates were washed three times with distilled water and air-dried. The slices were sealed with glycerogelatin. Osteoclast-like cell morphology, including cellular configuration, size, and nuclei, was observed under a microscope (BX40, Olympus, Tokyo, Japan).

Scanning electron microscopy of osteoclasts. Areas of the resorption pits in the bone slices formed by the osteoclasts may reflect the resorption activity. The bone slices were removed and cleaned ultrasonically three times for $10 \mathrm{~min}$ each in a $0.25 \mathrm{M} \mathrm{NH}_{4} \mathrm{OH}$ solution to remove adherent cells. They were then rinsed with PBS, fixed in $2.5 \%$ (v/v) glutaraldehyde (Sigma-Aldrich), postfixed in $1 \%$ osmium tetroxide (Sigma-Aldrich), dehydrated with a graded alcohol series, and placed in alcohol with isopentyl acetate. Finally, the bone slice samples were subjected to $\mathrm{CO}_{2}$ critical-point drying and gold staining, and the resorptive lacunae were observed by scanning electronic microscopy (JSM-6380LV, Jeol, Tokyo, Japan)

Experimental model. Marrow cells were harvested from the femors and tibias of the rat and cultured in 6-well chamber slides. The marrow cells were cultured in $\alpha$-MEM containing 10\% FBS, $1 \%$ penicillin-streptomycin (North China Pharmaceutical Co., Ltd., Shijiazhuang, China), and M-CSF $(25 \mathrm{ng} / \mathrm{ml})$. After $24 \mathrm{~h}$, non-adherent cells were collected and seeded into 6 -well culture plates $\left(1 \times 10^{6} \mathrm{cell} / \mathrm{s} /\right.$ well $)$. Osteoclast-like cells were randomly and equally divided into 
Table I. Primer sequences, product size, and condition for reverse transcription-quantitative polymerase chain reaction analysis.

Gene $\quad$ Primer sequences $\left(5^{\prime}-3 '\right)$

Product

NFATC

F: TTGGATTCTGACGAGCTGTG

F: TTGGATTCTGACGAGCTGTG
R: GTGCAGCTGGATCAAGAACA

(30) $95^{\circ} \mathrm{C}, 15 \mathrm{sec} ; 60^{\circ} \mathrm{C}, 60 \mathrm{sec} ; 60^{\circ} \mathrm{C}, 60 \mathrm{sec}$

209

$\mathrm{c}-\mathrm{Src}$

F: ACTGTCACCT-CCCCACAAAG

(30) $95^{\circ} \mathrm{C}, 15 \mathrm{sec} ; 60^{\circ} \mathrm{C}, 60 \mathrm{sec} ; 60^{\circ} \mathrm{C}, 60 \mathrm{sec}$

R: GACATTCCACCTTCCTCGTGT

RANK

F: GCCAGCAAGAAGTGTGTGAA

(30) $95^{\circ} \mathrm{C}, 15 \mathrm{sec} ; 60^{\circ} \mathrm{C}, 60 \mathrm{sec} ; 60^{\circ} \mathrm{C}, 60 \mathrm{sec}$

R: CCGGTCCGTGTACTCATCT

GAPDH

(30) $95^{\circ} \mathrm{C}, 15 \mathrm{sec} ; 60^{\circ} \mathrm{C}, 60 \mathrm{sec} ; 60^{\circ} \mathrm{C}, 60 \mathrm{sec}$

NFATc1, nuclear factor of activated T-cells, cytoplasmic, calcineurin-dependent 1; RANK, receptor activator of nuclear factor $\kappa B$; GAPDH, glyceraldehyde 3-phosphate dehydrogenase.

the M-CSF (25 ng/ml) group, M-CSF (25 ng/ml)+RANKL $(50 \mathrm{ng} / \mathrm{ml})$ group, M-CSF $(25 \mathrm{ng} / \mathrm{ml})+\mathrm{RANKL}(75 \mathrm{ng} / \mathrm{ml})$ group and M-CSF (25 ng/ml)+RANKL (100 ng/ml) group and cultured in 6-well plates for 9 days. NFATc1, c-Src and RANK mRNA assays were subsequently performed on the 9th day.

Reverse transcription-quantitative polymerase chain reaction analysis. Total RNA was isolated using TRIzol reagent (Invitrogen, Thermo Fisher Scientific Inc.). First-strand cDNAs were synthesized from $2 \mu \mathrm{g}$ of total RNA in $20 \mu \mathrm{l}$ reactions using the RevertAid first strand cDNA synthesis kit (Thermo Fisher Scientific Inc.). Each sample was analyzed in triplicate. The light cycler-fast start DNA master SYBR green (Roche, Thermo Fisher Scientific Inc.) was used according to the manufacturer's instructions. qPCR was conducted in a real-time PCR cycler (ABI7500, Applied Biosystems, Thermo Fisher Scientific Inc.). Primers were synthesized by Sangon Biotech Shanghai, Co., Ltd. (Shanghai, China). The primer sequences, product size, and cycling conditions are shown in Table I. The relative mRNA levels of NFATc1, RANK and c-Src were normalized to glyceraldehyde 3-phosphate dehydrogenase (GAPDH) mRNA. Four samples from each group were included in each experiment, and experiments were conducted at least three times. All reactions were run in triplicate, and data were analyzed using the $2^{-\Delta \Delta \mathrm{Cq}}$ method (19).

Statistical analysis. All values were expressed as the mean \pm standard deviation. One-way analysis of variance followed by the Least Significant Difference multiple comparison procedure was performed using SigmaStat 17.0 (SPSS Inc., Chicago, IL, USA). P $<0.05$ was considered to indicate a statistically significant difference.

\section{Results}

Cell observation. Cells were observed using an inverted phase contrast microscope. The TRAP-positive cells with three nuclei were counted as osteoclasts (Fig. 1). The osteoclasts

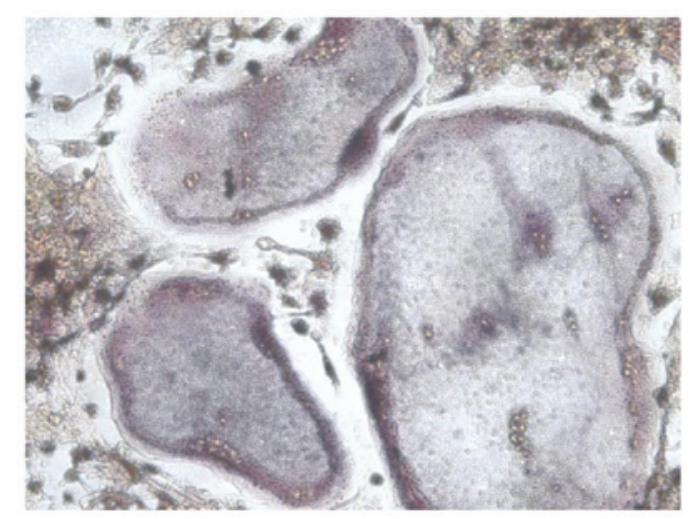

Figure 1. Osteoclasts stained with tartrate-resistant acid phosphatase (magnification, $\mathrm{x} 100)$.

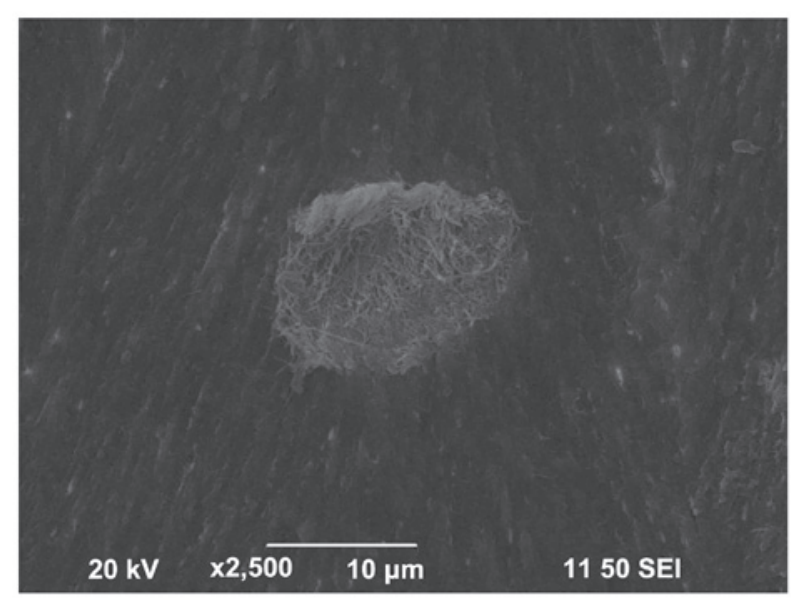

Figure 2. Scanning electron microscopic image of a bone slice surface cultured with marrow cells for 5 days. Irregular shape of the pit was clearly observed (magnification, x2,500).

varied in shape when observed under the scanning electron microscope. At the edge of cells, there were a large number of pseudopodia-like protrusions. It formed a typical bone resorption on the bone slices. The bone resorption was round, 


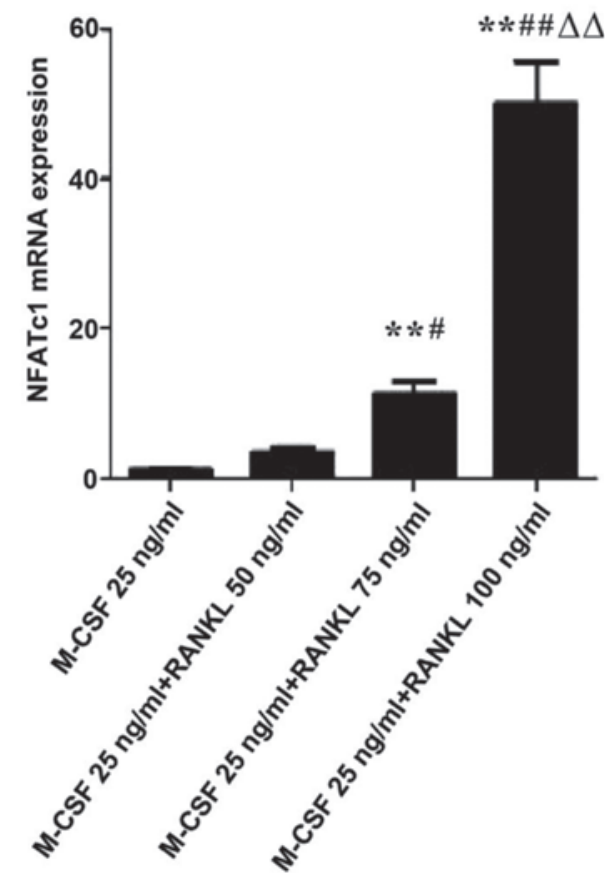

Figure 3. Effect of different concentrations of RANKL on the expression of NFATc1 mRNA in rat osteoclast-like cells. RANKL induced the expression of NFATc1 mRNA. ${ }^{* *} \mathrm{P}<0.01$, compared with the M-CSF $(25 \mathrm{ng} / \mathrm{ml})$ group. ${ }^{\#} \mathrm{P}<0.05$ and ${ }^{\# \#} \mathrm{P}<0.01$ compared with the M-CSF $(25 \mathrm{ng} / \mathrm{ml})+$ RANKL $(50 \mathrm{ng} / \mathrm{ml})$ group. ${ }^{\Delta \Delta} \mathrm{P}<0.01$, compared with the M-CSF $(25 \mathrm{ng} / \mathrm{ml})+\mathrm{RANKL}$ (75 ng/ml) group. RANKL, receptor activator of nuclear factor- $\mathrm{kB}$ ligand; NFATc1, nuclear factor of activated T cells cytoplasmic, calcineurin dependent 1; M-CSF, macrophage colony-stimulating factor.

oval or irregular. The bottom of the bone lacunae was rough and had fibrous substrate (Fig. 2).

Regulation of NFATc1, $c$-Src and RANK mRNA expression. Given that RANKL induces osteoclast activation, it was examined whether RANKL could regulate the gene expression of NFATc1, c-Src and RANK, which is known to be associated with osteoclast activation and function. As shown in Figs. 3-5, RANKL induced the expression of various osteoclast-activating genes, different concentrations of RANKL induced the expression of NFATc1, c-Src and RANK mRNA. NFATc1, c-Src and RANK mRNA expression in osteoclast-like cells following treatment with different concentrations of RANKL. Compared with the M-CSF $(25 \mathrm{ng} / \mathrm{ml})+$ RANKL $(0 \mathrm{ng} / \mathrm{ml})$ control group, the levels of NFATc1 and c-Src mRNA expression were significantly increased in the M-CSF (25 ng/ml)+RANKL (75 and $100 \mathrm{ng} / \mathrm{ml}$, respectively) groups $(\mathrm{P}<0.01)$. In addition, compared with the M-CSF $(25 \mathrm{ng} / \mathrm{ml})+$ RANKL $(0 \mathrm{ng} / \mathrm{ml})$ group, the levels of RANK mRNA expression were significantly increased in the M-CSF (25 ng/ml)+RANKL (50, 75 and $100 \mathrm{ng} / \mathrm{ml}$, respectively) groups $(\mathrm{P}<0.01)$. Compared with the M-CSF (25 ng/ml)+RANKL (50 ng/ml) group, the levels of NFATc1 mRNA expression were significantly increased in the M-CSF $(25 \mathrm{ng} / \mathrm{ml})+\mathrm{RANKL}(75$ and $100 \mathrm{ng} / \mathrm{ml})$ groups $(\mathrm{P}=0.013$ and $\mathrm{P}<0.01$, respectively). Compared with the M-CSF $(25 \mathrm{ng} / \mathrm{ml})+\mathrm{RANKL}(50 \mathrm{ng} / \mathrm{ml})$ group, the levels of c-Src mRNA expression were significantly increased in M-CSF (25 ng/ml)+RANKL (75 and $100 \mathrm{ng} / \mathrm{ml}$ ) groups

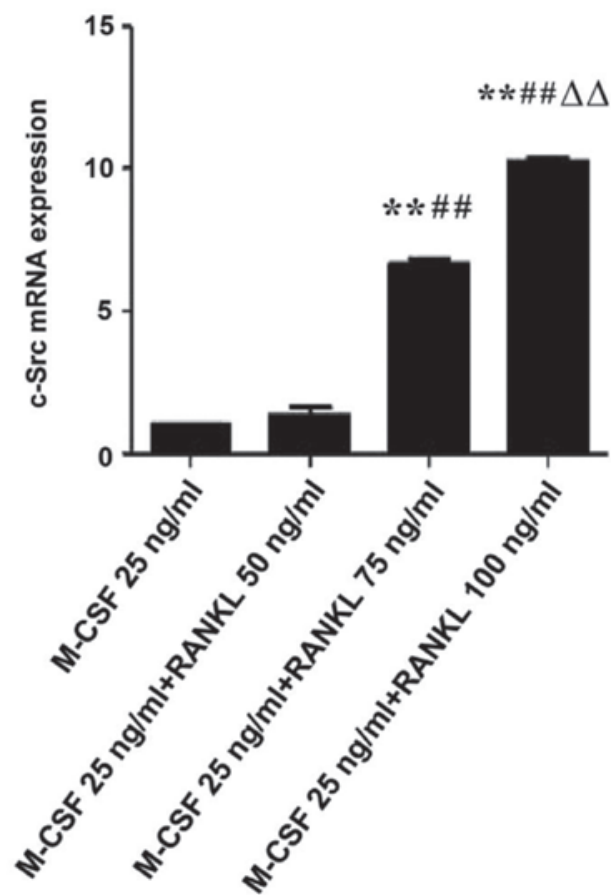

Figure 4. Effect of different concentrations of RANKL on the expression of c-Src mRNA in rat osteoclast like cells. RANKL induced the expression of c-Src mRNA. ${ }^{* *} \mathrm{P}<0.01$, compared with the M-CSF $(25 \mathrm{ng} / \mathrm{ml})+\mathrm{RANKL}$ (0 ng/ml) group. ${ }^{\# \#} \mathrm{P}<0.01$, compared with the M-CSF $(25 \mathrm{ng} / \mathrm{ml})+\mathrm{RANKL}$ (50 ng/ml) group. ${ }^{{ }^{\Delta} \mathrm{P}}<0.01$, compared with the M-CSF $(25 \mathrm{ng} / \mathrm{ml})+\mathrm{RANKL}$ (75 ng/ml) group. RANKL, receptor activator of nuclear factor- $\kappa \mathrm{B}$ ligand; NFATc1, nuclear factor of activated T cells cytoplasmic, calcineurin dependent 1 ; M-CSF, macrophage colony-stimulating factor.

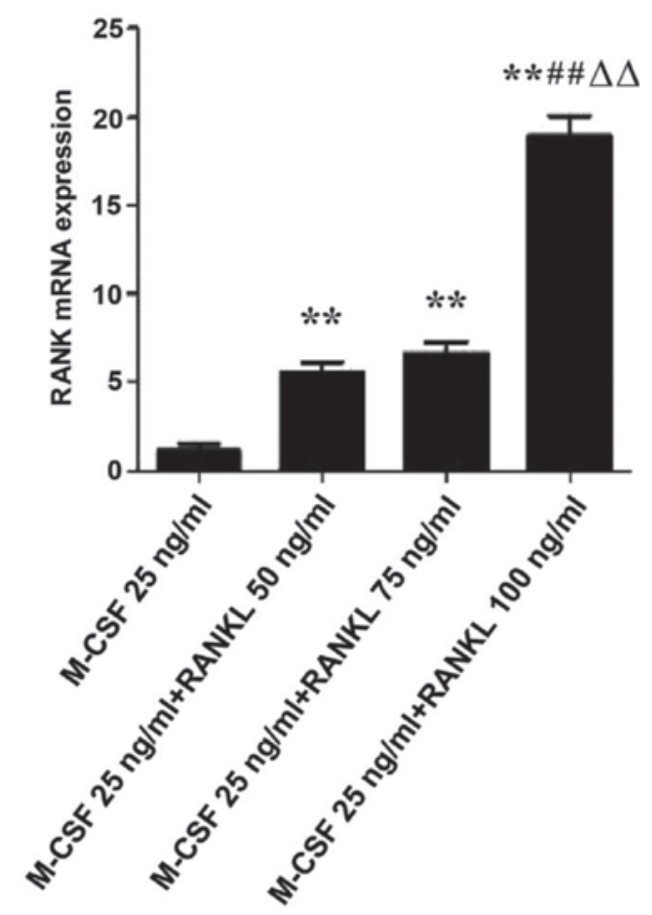

Figure 5. Effect of different concentrations of RANKL on the expression of RANK mRNA in rat osteoclast like cells. RANKL induced the expression of RANK mRNA. ${ }^{* *} \mathrm{P}<0.01$, compared with the M-CSF $(25 \mathrm{ng} / \mathrm{ml})+\mathrm{RANKL}$ $(0 \mathrm{ng} / \mathrm{ml})$ group. ${ }^{\# \#} \mathrm{P}<0.01$, compared with the M-CSF $(25 \mathrm{ng} / \mathrm{ml})+\mathrm{RANKL}$ (50 ng/ml) group. ${ }^{\Delta \Delta} \mathrm{P}<0.01$, compared with the M-CSF $(25 \mathrm{ng} / \mathrm{ml})+\mathrm{RANKL}$ $(75 \mathrm{ng} / \mathrm{ml})$ group. RANKL, receptor activator of nuclear factor- $\kappa \mathrm{B}$ ligand; NFATc1, nuclear factor of activated T cells cytoplasmic, calcineurin dependent 1; M-CSF, macrophage colony-stimulating factor. 
$(\mathrm{P}<0.01)$. Compared with the M-CSF $(25 \mathrm{ng} / \mathrm{ml})+\mathrm{RANKL}$ (75 ng/ml) group, the levels of NFATc1, c-Src and RANK mRNA expression were significantly increased in tge M-CSF $(25 \mathrm{ng} / \mathrm{ml})+\mathrm{RANKL}(100 \mathrm{ng} / \mathrm{ml})$ group $(\mathrm{P}<0.01)$.

\section{Discussion}

Osteoclast precursors that express RANK, a TNF receptor family member, recognize RANKL and differentiate into osteoclasts in the presence of M-CSF (3). M-CSF induces the proliferation of pre-osteoclasts cells, sustains their survival and stimulates the expression of RANK, the receptor of RANKL (20). RANKL expression by bone stromal cells, such as osteoblasts, synovial fibroblasts and T cells is increased adjacent to sites of pathological bone loss (17,21-23). Upon binding to its receptor RANK, RANKL activates multiple intracellular signaling pathways, including the MAPK and calcium dependent pathways, and ultimately stimulates transcription factors such as NF- $\kappa \mathrm{B}$, microphthalmia-associated transcription factor and NFATc1 $(9,24)$. NFATc1 is a critical transcription factor in osteoclastogenesis.

The targeted disruption of c-Src impairs osteoclast bone resorbing activity, causing osteopetrosis. Previous studies have demonstrated that osteoclast activation is mediated by various genes, including c-Src (14). c-Src protein, a member of the non-receptor tyrosine kinase family, was found to be highly expressed in osteoclasts (25). In addition, the expression of c-Src appeared to be under the control of RANKL at the transcriptional level in RAW264 mouse macrophage cells (26). Osteoclasts form normally in $\mathrm{Src}^{-}$mice but are unable to resorb bone due to lack of a ruffled border $(14,27)$. Namely, osteoclasts isolated from $\mathrm{Src}^{-/}$mice presented with an abnormal cytoskeletal structure, retarded cell migration, and consequently impaired bone resorbing activity $(15,28)$. While c-Src organizes the cytoskeleton of the cell in response to cytokines, it does not participate in RANKL-induced osteoclast formation.

NFATc1 and c-Src are master regulators of RANKL-induced osteoclast differentiation and the present study investigated the regulatory mechanism of NFATc1 and $\mathrm{c}-\mathrm{Src}$ in osteoclast activation. The principal aim of this study was to assess whether an increase in the concentration of RANKL was associated with changes in NFATc1, c-Src and RANK mRNA gene expression in osteoclast-like cells. It was demonstrated that the greater concentration of RANKL, the higher the expression of NFATc1, c-Src and RANK in rat osteoclast-like cells. The expression of NFATc1 appeared to be induced by RANKL stimulation. This further demonstrated that RANKL regulates the expression of NFATc1 and c-Src. These data suggest that NFATc1 is a key regulator of osteoclasts through induction of c-Src.

In conclusion, these data demonstrated that RANKL applied for 9 days could regulate the osteoclastic gene expression of NFATc1, c-Src and RANK. These results indicate that RANKL may modulate osteoclast activation and subsequent bone resorption through RANK and NFATc1. It also demonstrated that c-Src participates in the NFATc1 signaling pathway. This study suggests that decreasing the expression of NFATc1, c-Src and RANK mRNA or reducing the synthesis of RANKL may be a therapeutic strategy for the treatment of In order to treat various metabolic bone diseases.

\section{Acknowledgements}

This study was supported by grants from the National Natural Science Foundation of China (grant no. 81272168), the Technological Project of Health Bureau, Xiamen, Fujian Province, China (grant no. 3502Z20104031) and the Innovation Subject of Medicine in Fujian Province (grant no. 2012-CXB-32).

\section{References}

1. Alliston T and Derynck R: Medicine: Interfering with bone remodelling. Nature 416: 686-687, 2002.

2. Karsenty G and Wagner EF: Reaching a genetic and molecular understanding of skeletal development. Dev Cell 2: 389-406, 2002.

3. Theill LE, Boyle WJ and Penninger JM: RANK-L and RANK: $\mathrm{T}$ cells, bone loss, and mammalian evolution. Annu Rev Immunol 20: 795-823, 2002.

4. Walsh MC, Kim N, Kadono Y, Rho J, Lee SY, Lorenzo J and Choi Y: Osteoimmunology: Interplay between the immune system and bone metabolism. Annu Rev Immunol 24: 33-63, 2006.

5. Binder NB, Niederreiter B, Hoffmann O, Stange R, Pap T, Stulnig TM, Mack M, Erben RG, Smolen JS and Redlich K: Estrogen-dependent and $\mathrm{C}-\mathrm{C}$ chemokine receptor-2-dependent pathways determine osteoclast behavior in osteoporosis. Nat Med 15: 417-424, 2009.

6. Fata JE, Kong YY, Li J, Sasaki T, Irie-Sasaki J, Moorehead RA, Elliott R, Scully S, Voura EB, Lacey DL, et al: The osteoclast differentiation factor osteoprotegerin-ligand is essential for mammary gland development. Cell 103: 41-50, 2000.

7. Fuller K, Wong B, Fox S, Choi Y and Chambers TJ: TRANCE is necessary and sufficient for osteoblast-mediated activation of bone resorption in osteoclasts. J Exp Med 188: 997-1001, 1998.

8. Boyle WJ, Simonet WS and Lacey DL: Osteoclast differentiation and activation. Nature 423: 337-342, 2003.

9. Teitelbaum SL and Ross FP: Genetic regulation of osteoclast development and function. Nat Rev Genet 4: 638-649, 2003.

10. Takayanagi H, Kim S, Koga T, Nishina H, Isshiki M, Yoshida H, Saiura A, Isobe M, Yokochi T, Inoue J, et al: Induction and activation of the transcription factor NFATc1 (NFAT2) integrate RANKL signaling in terminal differentiation of osteoclasts. Dev Cell 3: 889-901, 2002

11. Zhou P, Sun LJ, Dötsch V, Wagner G and Verdine GL: Solution structure of the core NFATC1/DNA complex.Cell 92: 687-696, 1998.

12. Na KL: Molecular understanding of osteoclast differentiation and physiology. J Clin Endocr Metab 25: 264-269, 2010.

13. Ishida N, Hayashi K, Hattori A, Yogo K, Kimura T and Takeya T: CCR1 acts downstream of NFAT2 in osteoclastogenesis and enhances cell migration. J Bone Miner Res 21: 48-57, 2006.

14. Soriano P, Montgomery C, Geske R and Bradley A: Targeted disruption of the c-src proto-oncogene leads to osteopetrosis in mice. Cell 64: 693-702,1991.

15. Lakkakorpi PT, Nakamura I, Young M, Lipfert L, Rodan GA and Duong LT: Abnormal localisation and hyperclustering of alpha (v)beta (3) integrins and associated proteins in Src-deficient or tyrphostin A9-treated osteoclasts. J Cell Sci 114: 149-160, 2001.

16. Chen J, He JQ, Zheng SY and Huang LQ: OPG inhibits gene expression of RANK and CAII in mouse osteoclast-like cell. Rheumatol Int 32: 3393-3398, 2012.

17. Chen J, He CQ, Xia QJ, Huang LQ, Hu YJ and He CQ: Effects of pulsed electromagnetic fields on the mRNA expression of RANK and CAII in ovariectomized rat osteoclast-like cell. Connect Tissue Res 51: 1-7, 2010.

18. Pavlos NJ,Xu J,Riedel D, Yeoh JS, Teitelbaum SL, Papadimitriou JM, Jahn R, Ross FP and Zheng MH: Rab3D regulates a novel vesicular trafficking pathway that is required for osteoclastic bone resorption. Mol Cell Biol 25: 5253-5269, 2005.

19. Livak KJ and Schmittgen TD: Analysis of relative gene expression data using real-time quantitative PCR and the 2(-Delta Delta C(T)) Method. Methods 25: 402-408, 2001. 
20. Arai F, Miyamoto T, Ohneda O, Inada T, Sudo T, Brasel K, Miyata T, Anderson DM and Suda T: Commitment and differentiation of osteoclast precursor cells by the sequential expression of c-Fms and receptor activator of nuclear factor kappaB (RANK) receptors. J Exp Med 190: 1741-1754, 1999.

21. Crotti T, Smith MD, Hirsch R, Soukoulis S, Weedon H, Capone M, Ahern MJ and Haynes D: Receptor activator NF kappaB ligand (RANKL) and osteoprotegerin (OPG) protein expression in periodontitis. J Periodontal Res 38: 380-387, 2003.

22. Crotti TN, Smith MD, Findlay DM, Zreiqat H, Ahern MJ, Weedon H, Hatzinikolous G, Capone M, Holding C and Haynes DR: Factors regulating osteoclast formation in human tissues adjacent to peri-implant bone loss: Expression of receptor activator NFkappaB RANK ligand and osteoprotegerin. Biomaterials 25: 565-573, 2004.

23. Crotti TN, Smith MD, Weedon H, Ahern MJ, Findlay DM, Kraan M, Tak PP and Haynes DR: Receptor activator NF-kappa B ligand (RANKL) expression in synovial tissue from patients with rheumatoid arthritis, spondyloarthropathy, osteoarthritis, and from normal patients: Semiquantitative and quantitative analysis. Ann Rheum Dis 61: 1047-1054, 2002.
24. Hirotani H, Tuohy NA, Woo JT, Stern PH and Clipstone NA: The calcineurin/nuclear factor of activated $\mathrm{T}$ cells signaling pathway regulates osteoclastogenesis in RAW264.7 cells. J Biol Chem 279: 13984-13992, 2004.

25. Thomas SM and Brugge JS: Cellular functions regulated by Src family kinases. Annu Rev Cell Dev Biol 13: 513-609, 1997.

26. Kumagai N, Ohno K, Tameshige R, Hoshijima M, Yogo K, Ishida $\mathrm{N}$ and Takeya T: Induction of mouse c-src in RAW264 cells is dependent on AP-1 and NF-kappaB and important for progression to multinucleated cell formation. Biochem Biophys Res Commun 325: 758-768, 2004.

27. Lowe C, Yoneda T, Boyce BF, Chen H, Mundy GR and Soriano P: Osteopetrosis in Src-deficient mice is due to an autonomous defect of osteoclasts. Proc Natl Acad Sci USA 90: 4485-4489, 1993.

28. Boyce BF, Yoneda T, Lowe C, Soriano P and Mundy GR: Requirement of pp60c-src expression for osteoclasts to form ruffled borders and resorb bone in mice. J Clin Invest 90: 1622-1627, 1992. 